\title{
Factors Influencing the Intention to Use Open Educational Resources of Students at Universities in Economics and Business Administration in Vietnam
}

\author{
Quang Minh Doan ${ }^{1 *} \quad$ Thien Quoc Dao ${ }^{2}$ \\ 1.School of Information Technology and Digital Economics, National Economics University, 207 Giai Phong \\ Road, Hai Ba Trung District, Hanoi, Vietnam \\ 2.Library and Information Center, National Economics University, 207 Giai Phong Road, Hai Ba Trung District, \\ Hanoi, Vietnam
}

\begin{abstract}
The purpose of this paper is to examine the factors influencing the intention to use Open Educational Resources (OER) of students at universities in Economics and Business Administration in Vietnam. The results showed that Effort Expectancy, Performance Expectancy, Lecturer Influence, and Friend Influence were the factors had higher impact on the intention to use OER of students than other factors namely School Influence and Facilitating Conditions. Furthermore, regression analysis also pointed out that there were no relationship between control variables and students' intention to use OER. Finally, the paper also proposed several recommendations on how to implement Open Educational Resources initiatives effectively at higher education institutions in Vietnam.
\end{abstract}

Keywords: Intention to Use, Open Educational Resources, Universities in Vietnam.

DOI: $10.7176 / \mathrm{JESD} / 11-6-10$

Publication date:March $31^{\text {st }} 2020$

\section{Introduction}

The implementation of Open Educational Resources at higher education institutions is currently gaining momentum (Hylén 2006). Seaman (2015) states that an increasing number of higher education institutions have implemented some form of OER in their environment, and many more are seriously considering implementing OER in the near future to (1) share knowledge, (2) reuse available knowledge, (3) reduce cost of knowledge creation, and (4) conduct good public relations (Hylén 2006). In recent years, Open Educational Resources has also emerged as a key driver of change in the educational paradigm of universities to be more open since it promotes freely available educational resources for use, reuse, adaptation and sharing through the Internet (Wiley 2007). OER can therefore make a significant contribution to expanding educational opportunities for students studying at higher education institutions. Although OER has brought a number of undeniable benefits to the students, however, several OER initiatives have still experienced failed efforts or making minimal impact (Jung 2017), the reason can be that students who were successful in a traditional learning environment might not be successful in an online learning environment (Wood 2005). Lack of success in online learning can be several issues related to student motivation, self-discipline, and learner characteristics. Therefore, when using new learning methods or resources, it is critical to consider learner characteristics and motivation rather than merely introducing and applying new technology to an educational environment. It is especially significant to consider learners' needs and requirements in an educational paradigm shifting from a supplier-centered educational environment to a student-centered one. However, it is often to see that educational managers paying great attention to developing innovative teaching and learning methods for the effective utilization of technology while dedicating less effort to encouraging the use acceptance among students.

The belief that all learners can naturally use innovative technologies in an educational environment seems controversial (Oppenhimer 2003). Moreover, the application of new technology in education does not guarantee acceptance and use by learners (Kiraz \& Ozdemir 2006). Consequently, OER, as an innovation in the development and delivery of online educational resources, requires systematic analysis in order to improve its effects for learners. Given this need, it is critical to consider that the determining factors influencing the students' intention to use OER should be identified and thoroughly analysed, especially in Vietnam where this matter is very rarely mentioned and the phenomenon of OER is still in nascent stage. Thus, our research will address this issue. In more detail, the research intends to achieve the following objectives:

1. To specify determining factors influencing the intention to use OER of students at universities in Economics and Business Administration in Vietnam;

2. To explore and investigate the relationships between these factors and students' intention to use OER.

The remainder of this paper is structured as follows: Firstly, the literature and related work to the research are reviewed. Secondly, the research methodology is described. Thirdly, the data analysis and results are given. Finally, the paper concludes with further discussion of the findings, limitations of the research, and possible directions for future works. 


\section{Literature Review and Theoretical Framework}

\subsection{Open Educational Resource Initiatives in Higher Education}

The term "Open Educational Resources" was created at UNESCO's 2002 Forum on the Impact of Open Courseware for Higher Education in Developing Countries to describe a new global phenomenon of openly sharing educational resources in 2002. Open Educational Resources were defined as "technology-enabled, open provision of educational resources for consultation, use and adaptation by a community of users for non-commercial purposes" (UNESCO 2002). They are typically made freely available over the Web or the Internet. Their principal use is by teachers and educational institutions support course development, but they can also be used directly by students. Open Educational Resources include learning objects such as lecture materials, references and readings, simulations, experiments and demonstrations, as well as syllabi, curricula and teachers' guides.

The Open Educational Resources movement is growing in the higher education environment. Around the world there are currently over 2500 open access courses available from over 200 universities. Moreover, Open Educational Resources projects are also emerging at educational institutions in Australia, Brazil, Canada, Cuba, Hungary, India, Iran, Ireland, the Netherlands, Portugal, Russia, South Africa, Spain, Thailand, the United Kingdom, the United States, China, Hong Kong, South Korea, Tanzania, and Vietnam. OER offers multiple ways of teaching, learning, building, customizing, and sharing knowledge. Today, technology tools provide access to formal and informal education and stakeholders, such as learners, teachers, policymakers and administrators, who should explore ways to support open education and help students succeed. With OER, it is possible to reduce or eliminate the cost of textbooks, thus making higher education more affordable. While textbooks are generally recognized as important learning resources, published surveys of college students have shown that only a small percentage of students read the assigned textbook (Berry et al. 2010) or buy the required materials. In a survey of more than 20,000 postsecondary students in Florida, more than half students reported that the high cost of required textbooks determined their choice to not purchase them (Hilton 2016). While the cost of textbooks is a clear problem in advanced economies, it becomes yet a bigger issue in developing countries like Vietnam, where resources for instructors are scarce, or where access to formal classrooms is limited. OER can help students overcome those matters by offering them the learn-from-anywhere approach. Therefore, OER has great potential to support educational transformation in today's digital age.

\subsection{Factors Influencing the Intention to Use Open Educational Resources of Students}

A number of studies have identified factors affecting students' intention to use OER in various territories. In developing countries, network infrastructure has been found to be a significant factor of user readiness. For the case of China, Wang and Zhao (2011) found that only 37\% of universities provide wireless network in the campus, and only small number of colleges and universities have email service for their students (12.5\%). A similar situation is observed in Tanzania (Mtebe \& Raisamo 2014). Another critical factor is awareness of the existence of OER. It is found that some instructors and students are still unaware of OER's existence (Li 2013; Mtebe \& Raisamo 2014; Rolfe 2012). According to Mtebe and Raisamo (2014), many instructors and students also lack knowledge about copyright and intellectual property issues related to OER, they may thus hesitate to use and share OER with the fear of violating any copyright laws. Yan et al. (2013) also pointed out that due to cultural barrier, Hong Kong students showed little intent in accessing or sharing OER, if it was not assigned by teachers and didn't directly benefit their marks or assessment. While a number of studies focusing on factors influencing the intention to use OER of students have been conducted in many countries, this issue has never been mentioned in Vietnam. Thus this study will take into consideration the identified factors affecting students' intention to use OER, and examines to what extent they can apply to the case of Vietnam. 


\subsection{Theoretical Framework and Hypotheses}

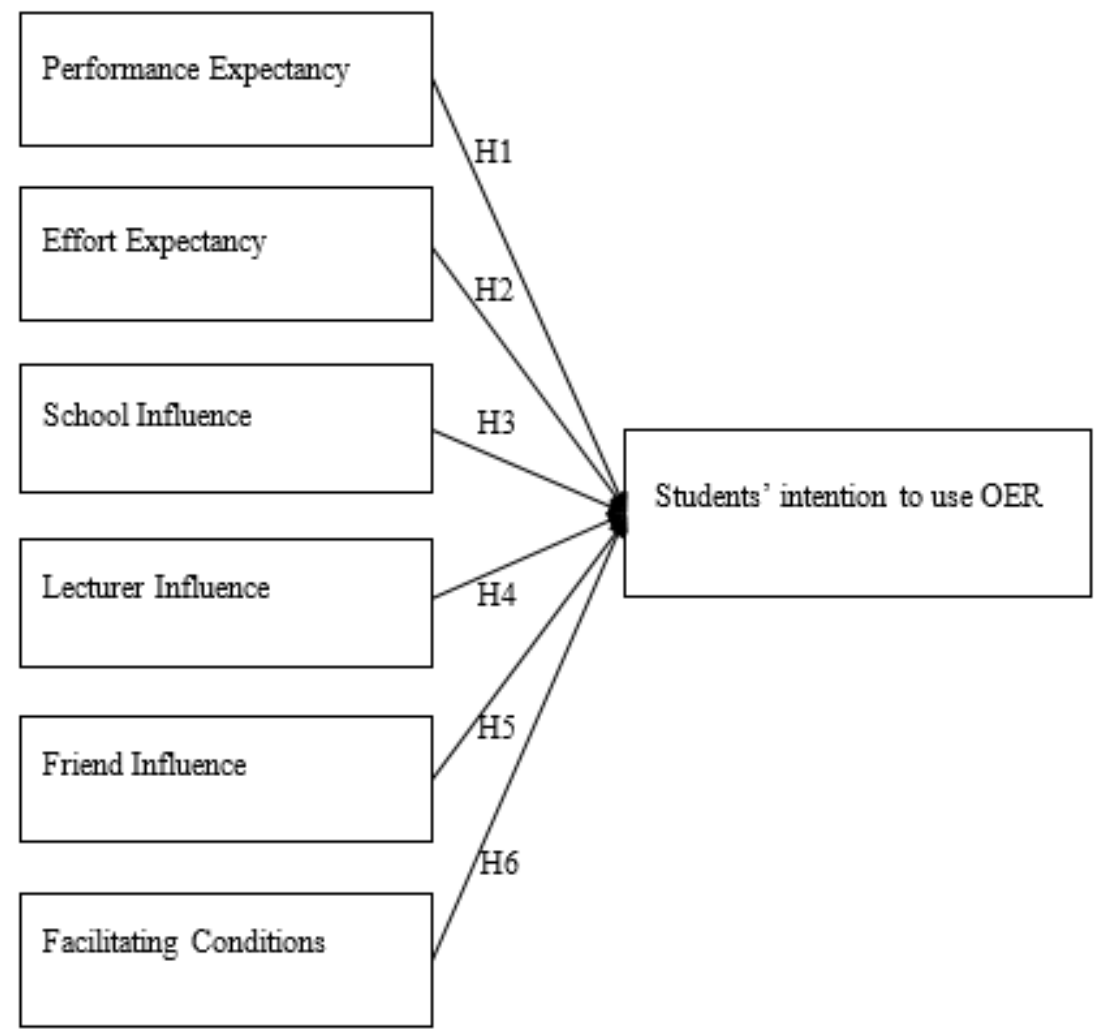

Figure 1. Proposed theoretical framework adapted from UTAUT model

This study adopts the unified theory of acceptance and use of technology (UTAUT) model (Venkatesh et al. 2003) to examine factors influencing the students' intention to use OER. The model combines eight dominant theories or models of technology acceptance, namely, theory of reasoned action (TRA), technology acceptance model (TAM), motivation model (MM), theory of planned behaviour (TPB), a combined theory of TPB and TAM (C-TPB-TAM), model of PC utilization (MPCU), innovation diffusion theory (IDT), and social cognitive theory (SCT). It is chosen for its established robustness and validity in predicting the acceptance of new technologies in a way better than any of its eight component models (Venkatesh et al. 2003), and widely use in studies regarding the acceptance of OER (e.g. Dulle \& Minishi-Majanja 2011; Mtebe \& Raisamo 2014; Percy \& Belle 2012). Based on the UTAUT model, the theoretical framework represented in the Figure 1 is developed by adjusting the Social Influence factor to become three component factors such as School Influence, Lecturer Influence, and Friend Influence. This adjustment is considered necessary because it is appropriate to the context of students studying at the universities as well as Vietnamese culture.

2.3.1. Performance expectancy

According to Venkatesh et al. (2003), performance expectancy refers to the degree to which a student believes that using OER will help him or her gaining in some sorts of performance (e.g. having a good learning outcome). Therefore, students will likely use OER if they think that using OER will bring to them a number of significant benefits. Thus, the following hypothesis could be developed:

Hypothesis 1 (H1). Performance expectancy will be positively related to students' intention to use OER.

2.3.2. Effort expectancy

According to Venkatesh et al. (2003), effort expectancy represents the degree of ease associated with using OER. Thus, students will likely use OER if they believe that the system is easy to use as well as the interaction with the system is clear and understandable. Hence, there is a hypothesis that:

Hypothesis 2 (H2). Effort expectancy will be positively related to students' intention to use OER.

2.3.3. School influence

School influence refers to the degree to which school has policies to encourage students using OER, such as using reference materials from OER to support students' learning is one of the school's regulations. Therefore, it is expected that:

Hypothesis 3 (H3). School influence will be positively related to students' intention to use OER.

2.3.4. Lecturer influence

Lecturer influence refers to the degree to which lecturers encourage students using OER, and always consider the ability to use OER as one of the criteria for evaluating students' learning ability. Consequently, the following 
hypothesis could be proposed:

Hypothesis 4 (H4). Lecturer influence will be positively related to students' intention to use OER.

2.3.5. Friend influence

Friend influence refers to the degree to which friends and classmates think that OER should be used to support their learning, and they are always willing to help each other in using OER. Therefore, there is a hypothesis that: Hypothesis 5 (H5). Friend influence will be positively related to students' intention to use OER.

2.3.6. Facilitating conditions

According to Venkatesh et al. (2003), Facilitating conditions are defined as the degree to which a student believes that an organizational and technical infrastructure exists to support use of OER. Thus, students will likely use OER if they are provided all the necessary conditions to access OER. Thus, the following hypothesis could be developed: Hypothesis 6 (H6). Facilitating conditions will be positively related to students' intention to use OER.

\section{Research Methodology}

\subsection{Sample and Data Collection}

The sample of the study consisted of undergraduate students studying in different disciplines at eight universities in Economics and Business Administration in Vietnam, including National Economics University, Banking Academy, University of Economics and Business Administration (Thai Nguyen University), Da Nang University of Economics (Da Nang University), University of Economics Ho Chi Minh City, Nguyen Tat Thanh University, Foreign Trade University, and Vietnam University of Commerce. 640 questionnaires were sent to the respondents. The survey was carried out in three months, from the 1st of June to the 29th of August 2019. As a result, 526 usable responses were received. The response rate was approximately $82 \%$. The detailed characteristics of the sample are presented in Table 1.

Table 1. Characteristics of the Sample $(\mathrm{N}=526)$

\begin{tabular}{|l|r|r|}
\hline \multicolumn{1}{|c|}{ Sample Characteristics } & Frequency & Percent \\
\hline Gender & 118 & \\
Boys & 408 & 22.4 \\
Girls & & 77.6 \\
\hline Age & 277 & \\
18 -20 years old & 249 & 52.7 \\
More than 20 years old & & 47.3 \\
\hline Disciplines & 106 & \\
Economics & 102 & 20.2 \\
Business Administration & 71 & 19.4 \\
Finance \& Banking & 66 & 13.5 \\
Accounting & 4 & 12.5 \\
Statistics & 8 & 0.8 \\
Management Information Systems & 16 & 1.5 \\
Law & 10 & 3.0 \\
Computer Science & 4 & 1.9 \\
Mathematics & 8 & 0.8 \\
Human Resource Management & 131 & 1.5 \\
Others & & 24.9 \\
\hline
\end{tabular}

\subsection{Questionnaire Development and Measures}

The questionnaire was developed using prior measurements corresponding to each variable in the literature and taking the context of the Vietnamese higher education into account. Each variable was measured by multiple items in order to increase the reliability of the measurements. Multi-item scales were used for measuring the variables using 5 -point Likert scale responses ranging from $1=$ strongly disagree to $5=$ strongly agree $(1=$ strongly disagree, 2 = disagree, $3=$ neutral, $4=$ agree, $5=$ strongly agree).

The survey composed of 26 multiple items/questions trying to measure the six independent variables (adapted from Venkatesh et al. 2003; Coleman-Prisco 2017; and self developed), and one dependent variable (taken from Venkatesh et al. 2003; Coleman-Prisco 2017). Firstly, respondents were asked to identify their level of agreement with each of the 23 questions related to the six independent variables, including Performance Expectancy, Effort Expectancy, School Influence, Lecturer Influence, Friend Influence, and Facilitating Conditions. Then, respondents were asked about their level of agreement with each of the three questions used for measuring students' intention to use OER. The statistical results indicated that Cronbach's alpha of each factor was greater than 0.7. According to Kline (1998), a set of items with a Cronbach's alpha greater than or equal to 0.7 is considered internally consistent. Following are the detailed results of factor analysis and reliability analysis for all constructs in the research model. 
Table 2. Results of factor and reliability analyses of six independent variables

\begin{tabular}{|c|c|c|c|c|c|c|}
\hline \multirow{2}{*}{ Items } & \multicolumn{6}{|c|}{ Factor loadings } \\
\hline & 1 & 2 & 3 & 4 & 5 & 6 \\
\hline $\begin{array}{l}\text { Performance Expectancy } \\
\text { (Cronbach's alpha=.844) } \\
\text { OER is useful in courses } \\
\text { Using OER will enable to accomplices course } \\
\text { development activities quickly } \\
\text { OER use will allow to have access to more information } \\
\text { Using OER would increase learning outcome students }\end{array}$ & $\begin{array}{l}.768 \\
.796 \\
.791 \\
.843\end{array}$ & & & & & \\
\hline $\begin{array}{l}\text { Effort Expectancy } \\
\text { (Cronbach's alpha }=.802 \text { ) } \\
\text { Interaction with OER is clear } \\
\text { Easy for using and integrating OER in courses } \\
\text { OER is easy to use } \\
\text { Learning to use OER is easy }\end{array}$ & & $\begin{array}{l}.762 \\
.716 \\
.789 \\
.738 \\
\end{array}$ & & & & \\
\hline $\begin{array}{l}\text { School Influence } \\
\text { (Cronbach's alpha }=.842 \text { ) } \\
\text { Using reference materials from OER to support students' } \\
\text { learning is one of the school's regulations } \\
\text { School always encourages the use of OER } \\
\text { School always supports the use of OER } \\
\text { School always has a reward mechanism for students who } \\
\text { actively use OER }\end{array}$ & & & $\begin{array}{l}.818 \\
.816 \\
.810 \\
.753\end{array}$ & & & \\
\hline $\begin{array}{l}\text { Lecturer Influence } \\
\text { (Cronbach's alpha= .887) } \\
\text { Lecturers always encourage the use of OER } \\
\text { Using OER is always recognized by lecturers } \\
\text { Using OER to support learning is a mandatory requirement } \\
\text { from the lecturers } \\
\text { Using OER is one of the criteria for evaluating students' } \\
\text { learning ability }\end{array}$ & & & & $\begin{array}{l}.856 \\
.862 \\
.859\end{array}$ & & \\
\hline $\begin{array}{l}\text { Friend Influence } \\
\text { (Cronbach's alpha }=.792) \\
\text { Friends and classmates think that OER should be used to } \\
\text { support their learning } \\
\text { Friends are willing to help in using OER } \\
\text { The use of OER is appreciated by friends }\end{array}$ & & & & & $\begin{array}{l}.683 \\
\\
.723 \\
.742 \\
\end{array}$ & \\
\hline $\begin{array}{l}\text { Facilitating Conditions } \\
\text { (Cronbach's alpha }=.813 \text { ) } \\
\text { You have the resources necessary to access OER } \\
\text { Technicians are always available to help you use OER } \\
\text { Access speed of OER system is always maintained stably } \\
\text { School provides free of charge Internet access }\end{array}$ & & & & & & $\begin{array}{l}.724 \\
.746 \\
.800 \\
.786 \\
\end{array}$ \\
\hline
\end{tabular}

Extraction Method: Principal Component Analysis. Rotation Method: Varimax with Kaiser Normalization. In a similar manner to the six independent variables, the Table 3 presents the results of factor and reliability analyses of students' intention to use OER.

Table 3. Results of factor and reliability analyses of students' intention to use OER

\begin{tabular}{|l|c|}
\hline \multicolumn{1}{|c|}{ Items } & Factor loadings \\
\cline { 2 - 2 } & \\
\hline Students' intention to use OER & \\
(Cronbach's alpha= .797) & .722 \\
You intend to use OER in the future & .753 \\
You predict you will use OER in the future & .698 \\
You have plan to use OER in the near future & \\
\hline
\end{tabular}

Extraction Method: Principal Component Analysis. Rotation Method: Varimax with Kaiser Normalization. Table 4 presents correlations of all variables in the research model. 
Table 4. Correlations among variables

\begin{tabular}{|c|c|c|c|c|c|c|}
\hline \multirow{2}{*}{ Variables } & \multicolumn{6}{|c|}{ Correlations } \\
\hline & 1 & 2 & 3 & 4 & 6 & 7 \\
\hline 1. Performance Expectancy & & & & & & \\
\hline 2. Effort Expectancy & $.276^{* *}$ & & & & & \\
\hline 3. School Influence & $.273 * *$ & $.275^{* *}$ & & & & \\
\hline 4. Lecturer Influence & $.160 * *$ & $.231 * *$ & $.207 * *$ & & & \\
\hline 5. Friend Influence & $.273 * *$ & $.275^{* *}$ & $.143 * *$ & $.163 * *$ & & \\
\hline 6. Facilitating Conditions & $.110 *$ & $.216^{* *}$ & $.091 *$ & $.165 * *$ & $.188 * *$ & \\
\hline 7. Students' intention to use OER & $.435^{* *}$ & $.583 * *$ & $.422 * *$ & $.412 * *$ & $.430 * *$ & $.346^{* *}$ \\
\hline
\end{tabular}

Note: $*$ Correlation is significant at the 0.05 level (2-tailed), ** Correlation is significant at the 0.01 level (2tailed).

\section{Results}

To test the hypothesis, a multiple regression analysis was conducted in order to see how students' intention to use OER is predicted and explained by the independent variables. The statistical result indicated that $57.7 \%$ of variance of the students' intention to use OER was explained and predicted by a set of independent variables $(\mathrm{p}<0.001)$. The detailed statistical result is presented in the Table 5.

Table 5. Regression results of the joint impact of all variables on students' intention to use OER

\begin{tabular}{|c|c|c|c|}
\hline $\begin{array}{r}\text { Dependen } \\
\text { (Students' intent }\end{array}$ & \multicolumn{3}{|c|}{$\begin{array}{c}\text { Dependent Variable } \\
\text { (Students' intention to use } O E R \text { ) }\end{array}$} \\
\hline Control Variables & \multicolumn{3}{|c|}{ Beta } \\
\hline Gender & \multicolumn{3}{|c|}{0.020} \\
\hline Age & \multicolumn{3}{|c|}{0.005} \\
\hline Disciplines & \multicolumn{3}{|c|}{0.048} \\
\hline \multicolumn{4}{|l|}{ Independent Variables } \\
\hline$\overline{\text { Performance Expectancy }}$ & \multicolumn{3}{|c|}{$0.218 * * *$} \\
\hline Effort Expectancy & \multicolumn{3}{|c|}{$0.314 * * *$} \\
\hline School Influence & \multicolumn{3}{|c|}{$0.186 * * *$} \\
\hline Lecturer Influence & \multicolumn{3}{|c|}{$0.207 * * *$} \\
\hline Friend Influence & \multicolumn{3}{|c|}{$0.193 * * *$} \\
\hline Facilitating Conditions & \multicolumn{3}{|c|}{$0.167 * * *$} \\
\hline Adjusted $\mathbf{R}^{2}$ & \multirow{2}{*}{\multicolumn{3}{|c|}{$\begin{array}{c}0.577 \\
80.827 * * *\end{array}$}} \\
\hline F Statistic & & & \\
\hline \multicolumn{4}{|l|}{ Note: $* * * \mathrm{p}<0.001$} \\
\hline \multicolumn{4}{|l|}{$\begin{array}{l}\text { The Table } 6 \text { summarizes all the results of the study. } \\
\text { Table } 6 \text {. Results of hypothesis testing }\end{array}$} \\
\hline Hypotheses & Beta & P value & Results \\
\hline $\begin{array}{l}\text { H1. Performance expectancy will be positively related to students' intention } \\
\text { to use OER }\end{array}$ & 0.218 & $\mathrm{P}<0.001$ & Supported \\
\hline $\begin{array}{l}\text { H2. Effort expectancy will be positively related to students' intention to use } \\
\text { OER }\end{array}$ & 0.314 & $\mathrm{P}<0.001$ & Supported \\
\hline $\begin{array}{l}\text { H3. School Influence will be positively related to students' intention to use } \\
\text { OER }\end{array}$ & 0.186 & $\mathrm{P}<0.001$ & Supported \\
\hline $\begin{array}{l}\text { H4. Lecturer influence will be positively related to students' intention to use } \\
\text { OER }\end{array}$ & 0.207 & $\mathrm{P}<0.001$ & Supported \\
\hline $\begin{array}{l}\text { H5. Friend influence will be positively related to students' intention to use } \\
\text { OER }\end{array}$ & 0.193 & $\mathrm{P}<0.001$ & Supported \\
\hline $\begin{array}{l}\text { H6. Facilitating conditions will be positively related to students' intention to } \\
\text { use OER }\end{array}$ & 0.167 & $\mathrm{P}<0.001$ & Supported \\
\hline
\end{tabular}

\section{Conclusion}

This study proposed and tested a theoretical framework that links the six independent variables, including Performance Expectancy; Effort Expectancy; School Influence; Lecturer Influence; Friend Influence; and Facilitating Conditions with intention to use OER of students at universities in Economics and Business Administration in Vietnam. It is found that Effort Expectancy, Performance Expectancy, Lecturer Influence, and Friend Influence were the most important factors influencing the students' intention to use OER. The findings also confirm that School Influence and Facilitating Conditions were positively associated with the intention to use OER 
of students. However, the influences of these factors remain weak.

Interestingly, the statistical results indicated that three control variables including Gender; Age; and Disciplines had no connection with the dependent variable. This finding obviously proved that students who are boys or girls, different age, or whatever disciplines they are studying in, had no too much difference in intention to use OER.

The findings of this study leads to several implications for improving effectiveness when implementing OER initiatives at universities in Economics and Business Administration in Vietnam. Firstly, it is expected that the OER system with friendly interface, easy to use, and good integration in courses will help increase students' learning outcome. Secondly, any suggestion, encouragement or reward from the lecturers or friends is truly necessary and will motivate students to use OER in their learning and doing research activities. Thirdly, using reference materials from OER to support students' learning should officially be one of the school's regulations. Moreover, school should also have a reward mechanism to recognize students who actively use OER. Finally, proper infrastructure, training classes, and facilitating conditions should be provided to support students effectively using the OER.

Although the study has made a number of considerable contributions on both theoretical and practical perspectives, it still reveals several limitations that need to be mentioned. The sampling procedure was not totally random due to several reasons, such as lack of time and budget. Therefore, the sample may not be representative for whole population of the study. Future research should try to use random sampling method to validate the results. Furthermore, the data validity may have been strengthened if additional in-depth interviews could be implemented. Spending more time for interviewing respondents would have provided additional data for analysis to investigate deeper into the issues.

\section{References}

Berry, T., Cook, L., Hill, N., \& Stevens, K. (2010), “An exploratory analysis of textbook usage and study habits: Misperceptions and barriers to success", College Teaching, 59(1), 31-39.

Coleman-Prisco, V. (2017), "Factors influencing faculty innovation and adoption of open educational resources in United States higher education”, International Journal of Education and Human Developments, 3(4), 1-12.

Dulle, F. W., \& Minishi-Majanja, M.K. (2011), "The suitability of the Unified Theory of Acceptance and Use of Technology (UTAUT) model in open access adoption studies", Information Development, 27(1), 32 - 45.

Hilton, J. (2016), "Open educational resources and college textbook choices: A review of research on efficacy and perceptions”, Educational Technology Research and Development, 64(4), 573-590.

Hylén, J. (2006) "Open educational resources: Opportunities and challenges", Paper presented at the 2006 Open Education Conference; https:/www.knowledgeall.com/files/Additional_Readings-Consolidated.pdf, accessed March 6th, 2020.

Jung, E., Bauer, C., \& Heaps, A. (2017), "Strategic Implementation of Open Educational Resources in Higher Education Institutions", Educational Technology, 57(2), 78-84.

Kiraz, E. \& Ozdemir, D. (2006), "The relationship between educational ideologies and technology acceptance in pre-service teachers", Educational Technology \& Society, 9(2), 152-165.

Kline, R. B. (1998), Principles and Practice of Structural Equation Modeling, London: Guilford Press.

Li, Y. (2013), "Constructing and sharing open educational resources: Policy and capacity" In J. Lam, K. C. Li, S. K. S. Cheung, \& F. L. Wang (eds.), Knowledge Sharing through Technology, New York: Springer-Verlag Berlin Heidelberg, 35-42.

Mtebe, J. S., \& Raisamo, R. (2014), "Challenges and instructors' intention to adopt and use open educational resources in higher education in Tanzania," The International Review of Research in Open and Distance Learning, 15(1).

Oppenheimer, T. (2003), The flickering mind: The false promise of technology in the classroom and how learning can be saved, NY: Random House.

Percy, P., \& Belle, J. P. V. (2012), "Exploring the barriers and enablers to the use of open educational resources by University academics in Africa”, In Hammouda I., Lundell B., Mikkonen T. \& Scacchi W. (Eds.), Open Source Systems: Long-Term Sustainability (IFIP AICT 378), Springer-Verlag, Berlin, 112-128.

Rolfe, V. (2012), “Open educational resources: Staff attitudes and awareness" Research in Learning Technology, 20.

Seaman, J., \& Tanya, M. S. (2015), “Opening public institutions: OER in North Dakota and the nation", https://www.onlinelearningsurvey.com/reports/2015openingthepublicsnd.pdf, accessed March 6th, 2020.

UNESCO (2002), "UNESCO Promotes New Initiative for Free Educational Resources on the Internet", http://www.unesco.org/education/news en/080702 free edu ress.shtml, accessed March 6th, 2020.

Venkatesh, V., Morris, M. G., Hall, M., Davis, G. B., Davis, F. D., \& Walton, S. M. (2003), "User acceptance of information technology: Toward a unified view", MIS Quarterly, 27(3), 425 - 478.

Wang, C., \& Zhao, G. (2011), Open Educational Resources in the People's Republic of China: Achievements, 
Challenges and Prospects for Development, Russia: UNESCO institute for information Technologies in Education.

Wiley, D. (2007), "On the sustainability of open educational resource initiatives in higher education", www.oecd.org/edu/oer, accessed March 6th, 2020.

Wood, C. (2005), "Highschool.com", Edutopia Magazine, 32-37.

Yan, K., Au, M., Chan, R., \& Tsang, C. (2013), “Open education: Challenges in Hong Kong”, In J. Lam, K. C. Li, S. K. S. Cheung, \& F. L. Wang (eds.), Knowledge Sharing through Technology, New York: Springer-Verlag Berlin Heidelberg, 212-226. 